measurements of corrosion made in different laboratories comparable. At the Rome Conference of Chemistry it was agreed that certain questions of chemical standardization should be discussed internationally. A further subject was the possible methods of testing chemical apparatus, which is notably subject to rapid wearing, without destroying it as is usual in engineering practice with test pieces. A second lecture on corrosion dealt with recent efforts to make metal vessels stand up to hydrochloric acid; this is one of the outstanding problems of the chemical industry.

\section{Dismissals of Scientists in Vienna}

IN addition to the scientific workers named in the letter under this title in Nature of June 18, p. 1101, Miss Margaret Gardiner has received the following further list of dismissals: University of Vienna : Prof. Emil Dittler, mineralogist ; Prof. Arnold Durig, physiologist; Prof. Kasimir Graff, astronomer; Prof. Friedrich Kottler, physicist; Prof. Karl Menger, mathematician; Prof. Hans Leitmeier, mineralogist; Prof. Hans Przibram, zoologist; Technical High School: Prof. Alfons Klemenc, chemist; Prof. Wolfgang Johannes Müller, chemist.

\section{Conference on Elasticity and Plasticity}

A CONFERENCE on "Elasticity and Plasticity" will be held under the auspices of the Institute of Physics (Manchester and District Branch) in the Physics Department of the University of Manchester on July 4-5. On July 4 the opening lecture by Prof. G. I. Taylor will take the form of a general theoretical survey, and will be followed by lectures on the elastic properties of metals by Dr. R. W. Bailey, and on the plastic properties of single crystals by Prof. E. N. da C. Andrade. On July 5, lectures will be given by Dr. F. T. Peirce on the elastic properties of fibres, by Dr. J. B. Speakman on the elastic properties of wool, and by Dr. W. G. Wearmouth on the elastic and plastic properties of synthetic resins. Each lecture will be followed by discussion. Visitors will be welcome. Further particulars may be obtained from the Honorary Secretary of the Branch, Dr. W. H. Taylor, Physics Department, College of Technology, Manchester, 1.

\section{Royal Sanitary Institute}

THE Health Congress of the Royal Sanitary Institute will be held at Portsmouth under the presidency of the Earl of Bessborough on July 11-16, when the following subjects among others will be discussed: the future of the general hospital, the defects found in school entrants and the steps to be taken before entering school life, behaviour and nervous diseases in children, food manufacturers' contributions to public health, the Food and Drugs Act 1937, meat and food inspection and air raid precautions. The Health Exhibition arranged in connexion with the Congress will include foods, sanitary appliances, and exhibits illustrating municipal action and hygiene in the home. Further information can be obtained from the Secretary of the Institute, 90 Buckingham Palace Road, London, S.W.1.

\section{Announcements}

The Committee of the Privy Council for the Organization and Development of Agricultural Research has appointed the Earl of Radnor, lord warden of the Stanneries, chairman of the Lawes Agricultural Trust, and a member of the Council of the Royal Agricultural Society of England, and (after consultation with the president of the Royal Society) Sir Joseph Barcroft, emeritus professor of physiology in the University of Cambridge, and formerly Fullerian professor of physiology in the Royal Institution, to be members of the Agricultural Research Council in succession to Lord Richard Cavendish and Sir Frederick Gowland Hopkins. Sir Thomas Middleton is succeeding Lord Richard Cavendish as chairman of the Council.

Prof. Max Planck, of Berlin, who is an honorary fellow of the Royal Society of Edinburgh, was the guest at a dinner held in his honour in the rooms of the Society on June 23. The president, Sir D'Arcy Wentworth Thompson, was in the chair.

Dr. W. H. George, lecturer in physics at University College, Southampton, has been appointed head of the Department of Physics at Chelsea Polytechnic, in succession to Dr. L. Lownds, who is retiring after thirty-seven years' service.

DR. C. E. Ford, demonstrator in botany, King's College, University of London, has been appointed geneticist to the Government Rubber Research Scheme, Ceylon.

Colonel Cecil Brat, late I.A.M.S., who died on March 18, left estate of the gross value of about $£ 35,000$. He bequeathed all his property, subject to life interest, to the Library Endowment Fund of the Royal Society of Medicine in appreciation of the services which the library renders to fellows.

The Selborne Society has started a fund for a memorial to the late Lord Leigh, who, during the ten years that he was president of its section which arranges visits to people and places of interest, took an active part in the work of the Society. Mrs. E. M. Richardson Rice, who introduced Lord Leigh to the Selborne Society in the year 1926, has consented to receive contributions at 67 Eardley Crescent, Earl's Court, S.W.5.

Prof. Heinrich Gins, director of the Robert Koch Institute for Infectious Diseases of Berlin, has been elected an honorary member of the Bulgarian Postgraduate Institute of Veterinary Surgeons.

AN international course in leprosy will be held on July 18-September 17 at the Institute of Malariology in Rome. The lectures, which are intended for foreign medical men, will be delivered in French. Further information can be obtained from the director of the Institute, Prof. G. Bastianelli, Policlinico Umberto 1, Roma. 